\title{
Foraging areas, migratory movements and winter destinations of blue whales from the western North Atlantic
}

\author{
Véronique Lesage $^{1, *}$, Katherine Gavrilchuk $^{1}$, Russel D. Andrews ${ }^{2,3}$, Richard Sears ${ }^{4}$ \\ ${ }^{1}$ Maurice Lamontagne Institute, Department of Fisheries and Oceans, Mont-Joli, Quebec G5H 3Z4, Canada \\ ${ }^{2}$ Alaska SeaLife Center, Seward, Alaska 99664-1329, USA \\ ${ }^{3}$ School of Fisheries and Ocean Sciences, University of Alaska Fairbanks, Fairbanks, Alaska 99775-7220, USA \\ ${ }^{4}$ Mingan Island Cetacean Study, St. Lambert, Quebec J4P 1T3, Canada
}

\begin{abstract}
The blue whale Balaenoptera musculus is a wide-ranging cetacean that can be found in all oceans. In the North Atlantic, little is known about blue whale distribution and genetic structure, or about the interconnections between areas of aggregations in Icelandic waters, the Azores, Northwest Africa, and the Northwest Atlantic. Seasonal movements and habitat use of blue whales, including the location of breeding and wintering areas, are also poorly understood. We used satellite telemetry to track movements of 23 blue whales from eastern Canada, providing the first record of the migratory movements and winter destinations of western North Atlantic blue whales. Cabot Strait, the largest outlet connecting the Gulf of St. Lawrence to the Atlantic, was identified as the main corridor for movements in and out of this high-latitude feeding area. The Mid-Atlantic Bight, located off the southeastern USA, was identified as a wintering, and possibly breeding or calving, area. We confirmed the extended use of key summer feeding areas in the St. Lawrence Estuary and northwestern Gulf of St. Lawrence into the fall, and provided evidence for new feeding areas off southern Newfoundland and Nova Scotia. Our results indicate that there is likely a strong connectivity among blue whale areas of concentration at northern latitudes. They also suggest sporadic foraging outside the feeding season, and highlight seamounts and other deep ocean structures as potentially important blue whale habitats. Globally, our study emphasizes the large scale (i.e. many thousands of square kilometers) one needs to consider when addressing the conservation issues faced by blue whale populations.
\end{abstract}

KEY WORDS: Blue whale $\cdot$ Migration $\cdot$ Movement $\cdot$ Wintering area $\cdot$ Habitat use $\cdot$ Foraging Atlantic $\cdot$ Area-restricted search

\section{INTRODUCTION}

The protection and recovery of vulnerable species, particularly those that are exposed to multiple natural or human pressures, is essential for maintaining biodiversity and ensuring ecosystem integrity and functioning (Dirzo et al. 2014). Determining the scale of seasonal movements and distribution, and identifying frequently used habitat, their periods of use,

*Corresponding author: veronique.lesage@dfo-mpo.gc.ca

$\S_{\text {Corrections were made after publication. For details see }}$ www.int-res.com/abstracts/esr/v34/c_p27-43/

This corrected version: July 26, 2017 and features rendering habitats suitable for vital functions such as breeding or foraging, are central to species conservation, and to the mitigation of impacts from global development (Hoenner et al. 2012). Advances in telemetry technologies exploiting the Argos satellites and, more recently, GPS have improved the remote tracking of wildlife over extensive distances and in hard-to-access places (Hussey et al. 2015). Although the size of tracking devices has

(c) R. D. Andrews, R. Sears and Fisheries and Oceans Canada 2017. Open Access under Creative Commons by Attribution Licence. Use, distribution and reproduction are unrestricted. Authors and original publication must be credited. 
limited their use in marine species such as seabirds and smaller fish, the main issue in cetaceans has been attachment difficulty, resulting in short retention times and insufficient data to interpret behaviour and movement patterns (Mate et al. 2007, Sulikowski et al. 2010, Hazen et al. 2012, Wilson \& Vandenabeele 2012, Balmer et al. 2014). Deployment durations improved considerably in cetaceans with the development of implantable tags designed to anchor deeply into blubber or muscle tissue (e.g. Mate et al. 2007). However, side effects such as localized to broad depression and swelling at the tag site persisting for days, months or even years were documented and associated with tags imbedded into muscle (Best \& Mate 2007, Robbins et al. 2013, Gendron et al. 2015). This raised concerns about potential shortand long-term health effects, and the trade-off between information gain and added perturbation to study populations (e.g. Robbins et al. 2013, Gendron et al. 2015). Recent miniaturization of tracking devices and the development of less invasive attachment designs has likely reduced detrimental health effects, rendering this technology more suitable for endangered populations (Andrews et al. 2008, Hussey et al. 2015).

The blue whale Balaenoptera musculus is a species for which our understanding of movement ecology has been limited in some regions by the conflict between technology and conservation status (reviewed in Geijer et al. 2016). While movement patterns have been well studied in some populations, such as in the eastern Pacific using implantable tags (e.g. Mate et al. 1999, Bailey et al. 2009), they remain largely unresolved for other populations, such as the western North Atlantic, where blue whales are considered endangered under the Canadian Species at Risk Act and the US Endangered Species Act. Blue whales are wide-ranging cetaceans that can be found in both coastal and oceanic habitats (Schoenherr 1991, Fiedler et al. 1998, Rice 1998, Sears \& Calambokidis 2002). Like other baleen whales, they are capital breeders that provision their offspring using previously stored energy (Houston et al. 2007). This characteristic allows separation of feeding and breeding areas. In blue and other baleen whales, seasonal movements are traditionally thought to occur between productive high-latitude feeding areas in summer, and oligotrophic, tropical or sub-tropical calving and mating areas in the winter, where feeding is absent (Kellogg 1929, Norris 1967). A recent review of the literature indicates that while this traditional model prevails for some species, sub-species or popula- tions, other movement strategies may also apply, including partial or differential migration, and flexible feeding throughout the migratory range (Geijer et al. 2016). While summer feeding areas have been described for some blue whale aggregations (e.g. Branch et al. 2007, Ramp \& Sears 2013), few studies have successfully tracked blue whale movements to and from wintering and breeding areas (Bailey et al. 2009, Double et al. 2014, Torres-Florez et al. 2015).

Blue whales in the North Atlantic Ocean belong to the subspecies B. m. musculus. Stranding and sighting data suggest a distribution ranging from Iceland, Svalbard (Norway), and Davis Strait (between Canada and Greenland) in the north, to New England (USA), the Caribbean, and West Africa (Senegal, Mauritania, and the Canary and Cape Verde Islands) in the south (reviewed in Sears \& Calambokidis 2002, Sears \& Larsen 2002). However, little is known regarding the genetic structure or interconnectedness between areas of aggregation, or the seasonal movements of blue whales in this ocean. Early whalers believed there were 2 populations in the North Atlantic (Ingebrigtsen 1929), although the International Whaling Commission never adopted this view (Donovan 1991). Recent satellite telemetry data from a few blue whales tagged in the eastern North Atlantic (Azores) have failed to support movements across the North Atlantic (Silva et al. 2013). These findings are in agreement with photo-identification studies suggesting a low degree of mixing between western and eastern North Atlantic blue whales (Sears \& Calambokidis 2002, Ramp \& Sears 2013). Currently, blue whales in the western North Atlantic are managed as a separate population under Canadian legislation.

In the western North Atlantic, the summer distribution of blue whales likely extends from Davis Strait to the Gulf of Maine in the eastern USA (Ingebrigtsen 1929, Jonsgård 1955, Wenzel et al. 1988, Sears \& Larsen 2002). During the summer, blue whales are reported from several areas in eastern Canadian waters, including the St. Lawrence Estuary (SLE) and the Gulf of St. Lawrence (GSL) (Ramp \& Sears 2013), off southern Newfoundland near the French islands of St. Pierre et Miquelon (Desbrosse \& Etcheberry 1987), and near or in some canyons along the shelf edge off Nova Scotia (Wimmer \& Whitehead 2004, Whitehead 2013). Passive acoustic monitoring systems deployed in US waters also indicated the presence of blue whales both near and off the shelf edge in southern Newfoundland and the Grand Banks (Clark 1995). Other than these limited observations, 
data on blue whale distribution, movement patterns, and habitat use in the western North Atlantic are extremely sparse, the notable exception being the SLE and northwestern GSL, where there has been sustained research effort during the summer and early fall over the past 35 years (Doniol-Valcroze et al. 2007, 2012, Ramp \& Sears 2013; but see Stenson et al. 2003, Whitehead 2013). Stranding and whaling reports suggest that the blue whale winter range may extend as far south as the Caribbean and the Gulf of Mexico (Clark 1995, Sears \& Calambokidis 2002, Reeves et al. 2004). Blue whale vocalizations have been detected near the Mid-Atlantic Ridge in winter, suggesting that some individuals migrate to the central Atlantic; however, it is unknown whether these whales were from the east, west, or both (Nieukirk et al. 2004).

In this study, we attached small location-only satellite telemetry devices to blue whales from eastern Canada in early fall to track their local and migratory movements, with the aim of identifying key foraging areas, transiting corridors, and their winter breeding or calving areas.

\section{MATERIALS AND METHODS}

\section{Data collection}

Twenty-four blue whales were equipped with satellite-linked platform terminal transmitters (PTTs or tags) between 30 August and 18 November 2002 and 2010-2015 (except 2011). Deployments were made in eastern Canada, off the Gaspé Peninsula in the GSL, and at various sites in the SLE (Fig. 1). All recent (2010-2015) deployments involved SPOT5 location-only Argos PTTs in the LIMPET configuration (Wildlife Computers). The single deployment made in 2002 used a custom-designed implantable PTT (Sirtrack) inserted into a 16-18 cm long casing made of surgical cement and surgical steel. Tags were fastened onto the tip of a carbon-fibre arrow using a quick-release mechanism, and discharged from a distance of 4 to $7 \mathrm{~m}$ using either a crossbow (in 2002) or a $\mathrm{CO}_{2}$-powered rifle with adjustable pressure (JM Special 25 model, DAN-INJECT) (in 2010-2015). The 2002 tag was made to anchor into the blubber, whereas recent tags were designed to

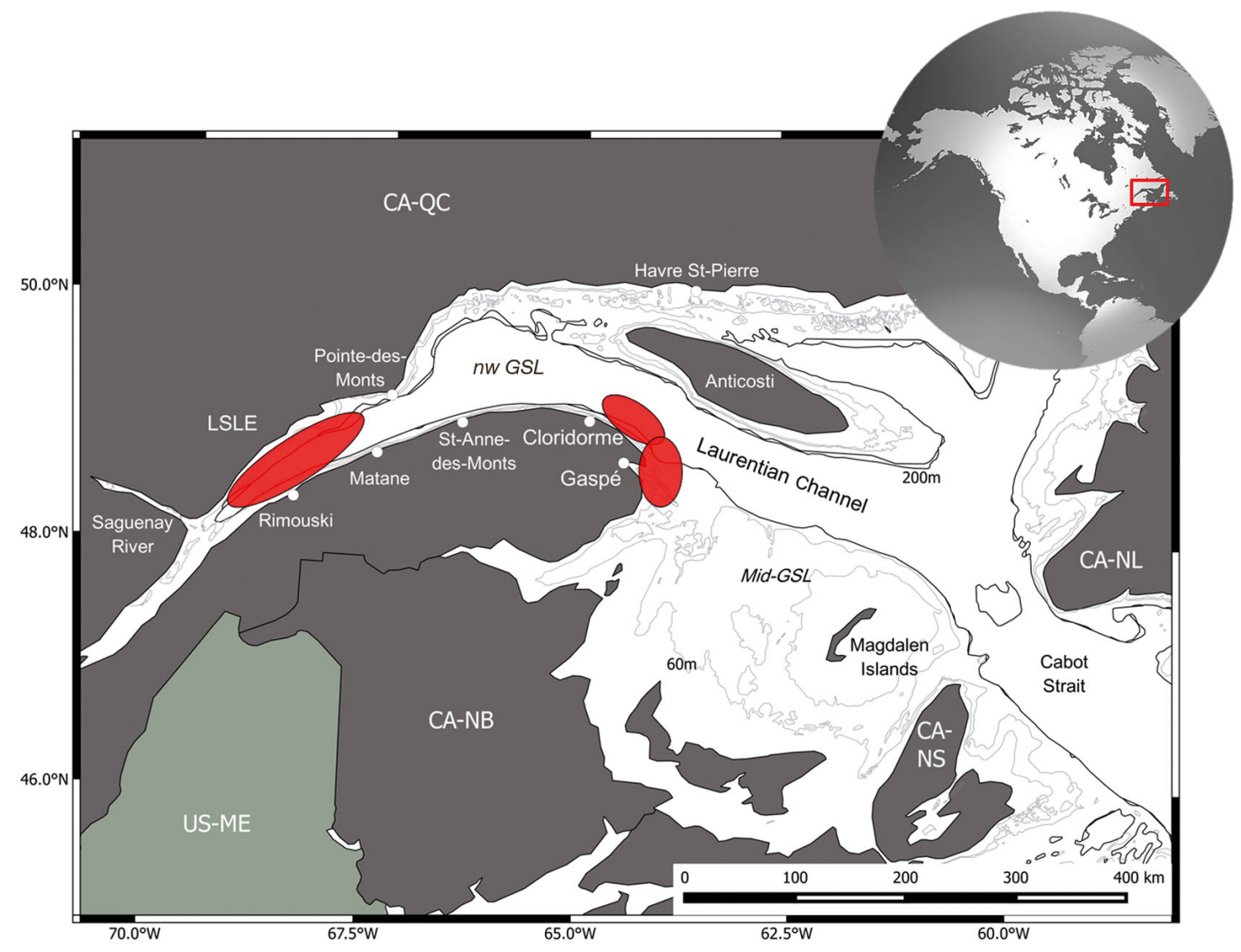

Fig. 1. Tagging locations (red ovals) of 24 blue whales in the Lower St. Lawrence Estuary (LSLE; $\mathrm{n}=15)$ and northwestern Gulf of St. Lawrence (GSL) off the Gaspé Peninsula ( $\mathrm{N}=9$ ), Canada, in 2002, and from 2010 to 2015 
be inserted into the dorsal fin. Choosing the dorsal fin as an anchoring site is a compromise. On the one hand, the tag has less time to communicate with passing satellites (since the dorsal fin tends to only be exposed when blue whales dive); on the other hand, dorsal fin tissue offers more resistance to anchored barbs than blubber and therefore likely prolongs tag retention time. The implantation system for the SPOT5 PTTs consisted of 2 titanium darts, each with 6 backwards-facing petals, which penetrated a maximum of $7 \mathrm{~cm}$ into the skin and sub-dermal tissue. The implantation system for the 2002 PTT also included a quickrelease system on impact, but consisted of 2 actively sprung plates and a circle of passively deployed petals to implant into the skin and blubber, often resulting in a third of the tag remaining outside of the body. This tag was attached near the shoulder (scapula) to increase exposure to passing satellites. All tagged whales were photo-identified (Sears et al. 1990) and matched to the western North Atlantic blue whale photo-identification catalogue, which was built over a 35-yr period (R. Sears, Mingan Island Cetacean Study, MICS). Gender data was available for some of the tagged whales by means of an ongoing tissue sampling program (R. Sears, MICS).

In 2002, tags were duty-cycled to transmit every other day; all other tags were programmed to transmit on a daily basis, every hour of the day, and up to a maximum of 300 messages per day. The position of the tag in or near the dorsal fin, combined with the short duration of a satellite pass (generally less than 15-17 min), limits the chances of a passing satellite to receive multiple transmissions from a PTT, and thus to provide high quality locations (3 messages or more). The odds of obtaining high-quality location data are further reduced by the long duration of blue whale dives (up to $23 \mathrm{~min}$ in the SLE) and short surface times (less than $4 \mathrm{~min}$ ) (Doniol-Valcroze et al. 2011). In order to maximize transmission opportunities during a satellite pass, the PTT repetition rate for successive transmissions was reduced to $15 \mathrm{~s}$ from the standard $45 \mathrm{~s}$.

The raw location data from 2002 were calculated using the Argos service-provided nonlinear least squares positioning algorithm, which was the only technique available at the time. For the period 20102015, real-time location data were initially processed using an interacting multiple model (IMM) Kalman filter, an Argos positioning algorithm released in 2014 which significantly reduced location estimate errors (Lopez et al. 2014, Silva et al. 2014). However, in 2015, Argos released a new processing algorithm (Lopez et al. 2015), said to substantially improve loca- tion accuracy, particularly when a limited number of messages ( 1 to 3 ) are available to estimate locations. Given our data, we chose to reprocess all raw Doppler data using this fixed-interval multiplemodel Kalman smoothing procedure (Lopez et al. 2015).

Location estimates were classified by Argos into 7 quality classes (LCs, in descending order of quality: $3,2,1,0, A, B$, and $Z$ ) according to the number of messages received by satellites, the time elapsed between these messages, and the time since a previous location was estimated (Austin et al. 2003). The spatial error associated with Kalman-filtered Argos locations has recently been quantified using seals equipped with both Argos and Fastloc GPS platforms; for location classes 3, 2, 1, and A, the 68th percentile of estimated errors was less than $1.3 \mathrm{~km}$, whereas for location classes 0 and $\mathrm{B}$, it was less than $2.4 \mathrm{~km}$ (Lowther et al. 2015).

\section{Switching state-space model}

The behaviour of remotely monitored animals can be inferred from a time series of location data. Animals tend to exhibit stochasticity in their movement paths, likely as a result of spatial variation in environmental characteristics, such as topography or prey density (Curio 1976, Gardner et al. 1989, Turchin 1991, Wiens et al. 1993). Predators are expected to decrease travel speed and/or increase turning frequency and turning angle when a suitable resource is encountered (Turchin 1991). This behaviour increases residency in specific areas and is known as area-restricted search (ARS). Occurrence of ARS may be associated with foraging or other behaviours with movement patterns leading to increased residency. In contrast, animals in transit or travelling tend to move at faster and more regular speeds, with infrequent and smaller turning angles (Kareiva \& Odell 1987, Turchin 1998).

To assess movement and behaviour of blue whales, we applied a Bayesian switching state-space model (SSSM) to Argos-derived telemetry data (Jonsen et al. 2005, 2013). A SSSM essentially estimates animal locations at fixed time intervals, as well as movement parameters and behavioural modes. A first-difference correlated random walk (DCRW) is used to model movement dynamics by assigning a distinct DCRW equation to 2 discrete behavioural modes, and allowing movement parameters to switch between each mode (in this case, transiting and ARS). Each DCRW model differs in its values of mean turn- 
ing angle $(\theta)$ and move persistence $(\gamma ;$ autocorrelation in speed and direction). A Markovian process model then describes the evolution of behaviour (b) through time by estimating the probability of switching states from transiting at time $t$ to ARS at time $t+1$ (Jonsen et al. 2013). By using Bayesian inference, 2 important sources of uncertainty can be measured separately: the estimation error resulting from inaccurate observations (Argos location error), and the process variability related to stochasticity in the movement process (behavioural mode estimation) (Jonsen et al. 2003, Patterson et al. 2008).

SSSMs can also be implemented under a hierarchical framework (hSSSM) by assuming individuals are 'samples' from a population, or that their movement and behaviour parameters come from a common distribution (Jonsen et al. 2003, 2006, Mills Flemming et al. 2010). The advantage of this approach is to reduce uncertainty of parameter estimates at the individual level by simultaneously evaluating location information from multiple individuals of a population (Morales et al. 2004, Jonsen et al. 2006). The process model of the hSSSM (Jonsen et al. 2007) can be formulated as follows:

$$
d_{t, k} \sim N_{2}\left(\gamma_{b t, k} \mathbf{T}\left(\theta_{b t, k}\right) d_{t-1, k} \Sigma\right)
$$

where $k$ represents each individual whale, $d_{t, k}$ is the displacement of whale $k$ from unobserved location $x_{t}$ to $x_{t-1}$, and $d_{t-1, k}$ is the displacement of whale $k$ between unobserved locations $x_{t-1}$ and $x_{t-2}$. The transition matrix $\mathbf{T}(\theta)$ specifies the rotation required to move from $d_{t-1}$ to $d_{t}$, where $\theta$ is the mean turning angle. $\gamma$ is the move persistence coefficient (combined autocorrelation in direction and speed). $N_{2}$ is a bivariate Gaussian distribution with covariance matrix $\Sigma$, representing the variability in animal movement. The behavioural mode $b_{t}$ is a continuous variable ranging from 1 to 2 , and is indexed by combining parameters $\theta$ and $\gamma$ estimated from the process model (Morales et al. 2004). Behavioural mode values closer to 1 are taken to represent transiting, while values closer to 2 reflect an ARS movement pattern. Previous studies have adopted conservative cut-off values to readily bin behaviour, where mean estimates of $b \leq 1.25$ represent transiting, $b \geq 1.75$ ARS, and values in between $(1.25<b<1.75)$ are considered uncertain, or without sufficient information to clearly distinguish behaviours (Jonsen et al. 2005).

Only individuals with a minimum of 3 PTT days were retained for the hSSSM analysis. Tracks with PTT days under this threshold, or with temporal gaps in positional data in excess of $4 \mathrm{~d}$ resulted in poor model fit. In order to keep a maximum of information, and reduce uncertainty for the days without position data, tracks with data gaps $>4 \mathrm{~d}$ were split into 2 or more sub-tracks. Priors used on movement parameters are similar to those from previous studies (Bailey et al. 2009, Jonsen et al. 2013, Kennedy et al. 2014, Silva et al. 2013, Prieto et al. 2014) and assume that during transiting, turn angles should be closer to $0^{\circ}$ and autocorrelation in speed and direction should be higher than during ARS. Blue whale locations and movement parameters were modelled at a regular time step adapted to the temporal resolution of the data. The hSSSM ran 2 parallel Markov chain Monte Carlo (MCMC) chains, each comprising 180000 iterations. The first 100000 samples were discarded as a burn-in, and the remaining samples were thinned by retaining every 15th sample to reduce sample autocorrelation. Convergence and sample autocorrelation were assessed by visually inspecting trace and autocorrelation plots. Based on the resolution of our location data, we chose to estimate whale locations and behaviour at a regularized 4 -h time interval. We also explored the use of a wider temporal resolution $(6 \mathrm{~h})$ on location and movement parameter estimates, as well as on the location and number of ARS patches (see below), and the proportion of locations assigned to each behavioural mode. Mean swimming speed associated with each behaviour was calculated as the distance $(\mathrm{km})$ between successive hSSSM-estimated locations divided by the associated time step.

The R package bsam was used to fit the hSSSM (code available from Jonsen et al. 2013) via an MCMC sampler executed in JAGS 3.1.0 (Just Another Gibbs Sampler, created and maintained by M. Plummer, http://mcmc-jags.sourceforge.net).

Potential foraging areas (or ARS patches) were defined as 3 or more successive locations in which ARS behaviour was predicted (behavioural mode $b \geq$ 1.75), and ending with 3 consecutive locations assigned a $b$-value $<1.75$ (Bailey et al. 2009). ARS patches were geographically presented using a line connecting successive ARS locations, each buffered with a radius equal to the average error $(8.35 \mathrm{~km})$ for our predominant location quality class (B, 83\% of locations; see Table S1 in the Supplement at www. int-res.com/articles/suppl/n034p027_supp.pdf). The location, number, and duration of ARS patches were determined for each individual track and for all tracks combined to give an estimate of populationlevel ARS dynamics in the study area. Relationships between these variables were first examined using linear models. Generalized additive mixed models using individual whale as a random effect were 
applied in cases where non-linear patterns were detected.

We defined initiation of migratory movement (or departure) out of the GSL as a consecutive period of $\geq 48 \mathrm{~h}$ of hSSSM-predicted transiting behaviour (i.e. $b$ values $\leq 1.25$ ). This definition of departure differed slightly from that used in Silva et al. (2013) due to the nature of our study area. For example, Silva et al. (2013, p. 4) defined departure based on movement speed: 'the first of $\geq 48$ consecutive hours with the whale travelling at speeds higher than the median ARS speed estimated from all whale tracks'. In our case, the first bout ( $\geq 48 \mathrm{~h}$ ) with movement speeds exceeding our blue whale median ARS speed did not necessarily represent departure from the feeding ground, since it took some whales $2 \mathrm{~d}$ to move from ARS patches in the SLE to ARS patches in the mid-GSL. However, by adopting the $\geq 48 \mathrm{~h}$ consecutive hours of hSSSM-predicted transiting behaviour (determined using a combination of turning angle and autocorrelation in speed and direction), we were able to suitably capture the onset of blue whale migration out of the gulf.

\section{RESULTS}

\section{Summary of deployments}

Twenty-three of the 24 blue whales equipped with Argos satellite transmitters successfully provided location data (Table 1). All whales were photo-identified (except one), confirming that distinct individuals were tagged. Sixteen of the tagged whales were of known sex, including an equal number $(n=8)$ of males and females. The delay period from tagging to first position received ranged from 0 to $34 \mathrm{~d}$. Half of the tags $(\mathrm{n}=12)$ began transmitting positions on the day of deployment. Periods of silence (days without positions) occurred during some of the deployments and ranged from 1 to $21 \mathrm{~d}$.

Given how small the dorsal fin in blue whales was as a target, the majority of PTTs were anchored at the base of the dorsal fin, an area where the tissue transitions to blubber. One tag, which we suspect was anchored in the fibrous tissue of an old scar, provided location data for 6 mo (177 d). Tag longevity (from

Table 1. Summary deployments for 24 blue whales equipped with Argos platform terminal transmitters (PTT) in the Estuary or Gulf of St. Lawrence, Canada. First and last location: date of first and last Argos location received; Delay: number of days between tagging and first position received; PTT lifetime: number of days between tagging date and last location received; Total PTT days: number of days positions were acquired; Valid locations: number of non-Z location class positions; Locations per day: no. of locations received per day; Time step: median number of hours elapsed between received locations (only for consecutive PTT days and tracks used in the hSSSM analysis); NA: not available

\begin{tabular}{|c|c|c|c|c|c|c|c|c|c|c|c|}
\hline PTT ID & $\begin{array}{c}\text { Whale } \\
\text { ID }\end{array}$ & Sex & $\begin{array}{c}\text { Tagging } \\
\text { date }\end{array}$ & $\begin{array}{c}\text { First } \\
\text { location }\end{array}$ & $\begin{array}{c}\text { Last } \\
\text { location }\end{array}$ & Delay & $\begin{array}{c}\text { PTT } \\
\text { lifetime }\end{array}$ & $\begin{array}{c}\text { Total } \\
\text { PTT days }\end{array}$ & $\begin{array}{c}\text { Valid } \\
\text { locations }\end{array}$ & $\begin{array}{c}\text { Locations } \\
\text { per day }\end{array}$ & $\begin{array}{c}\text { Time } \\
\text { step (h) }\end{array}$ \\
\hline 2002_36037 & B276 & $\mathrm{M}$ & 2002-09-04 & 2002-09-04 & 2002-09-29 & 0 & 26 & 19 & 128 & 6.7 & 1.7 \\
\hline 2010_100383 & B391 & $?$ & 2010-09-07 & 2010-09-11 & 2010-09-21 & 4 & 15 & 11 & 87 & 7.3 & 1.5 \\
\hline 2010_100384 & B434 & $?$ & 2010-09-07 & 2010-09-07 & 2010-10-07 & 0 & 31 & 31 & 327 & 10.6 & 0.9 \\
\hline 2012_106738 & B320 & $?$ & 2012-09-02 & 2012-09-02 & 2012-09-14 & 0 & 13 & 13 & 95 & 7.4 & 1.8 \\
\hline 2012_106739 & B161 & $\mathrm{M}$ & 2012-09-03 & 2012-09-03 & 2012-09-07 & 0 & 5 & 5 & 70 & 14.2 & 1.0 \\
\hline 2012_100386 & B324 & $\mathrm{F}$ & 2012-09-21 & 2012-09-24 & $2012-10-22$ & 3 & 32 & 7 & 21 & 2.8 & 2.7 \\
\hline 2012_100387 & B311 & $\mathrm{M}$ & 2012-09-26 & 2012-09-26 & 2012-12-04 & 0 & 70 & 70 & 520 & 7.4 & 1.8 \\
\hline 2012_100388 & B122 & $\mathrm{F}$ & 2012-09-28 & 2012-09-28 & 2012-10-15 & 0 & 18 & 18 & 224 & 12.5 & 1.2 \\
\hline 2013_106741 & B378 & $\mathrm{M}$ & 2013-09-05 & 2013-09-05 & 2013-09-25 & 0 & 21 & 18 & 165 & 9.2 & 0.8 \\
\hline 2013_106740 & B493 & $?$ & 2013-09-05 & NA & NA & NA & 0 & 0 & 0 & 0.0 & NA \\
\hline 2013_100386 & B458 & $?$ & 2013-09-26 & 2013-09-27 & 2013-10-11 & 1 & 16 & 15 & 129 & 8.1 & 1.3 \\
\hline 2013_100389 & NA & $?$ & 2013-09-27 & 2013-10-01 & 2013-12-02 & 4 & 67 & 16 & 95 & 5.6 & 1.4 \\
\hline 2013_106743 & B166 & F & 2013-09-28 & 2013-10-15 & 2013-11-02 & 17 & 36 & 3 & 15 & 3.8 & NA \\
\hline 2013_106742 & B347 & M & 2013-09-28 & 2013-09-29 & 2013-10-03 & 1 & 6 & 3 & 17 & 4.5 & 1.1 \\
\hline 2013_106734 & B485 & $?$ & 2013-09-28 & 2013-10-01 & 2013-10-07 & 3 & 10 & 3 & 21 & 5.5 & 0.9 \\
\hline 2013_106737 & B181 & $\mathrm{M}$ & 2013-10-01 & 2013-10-01 & 2013-10-25 & 0 & 25 & 16 & 83 & 5.6 & 1.7 \\
\hline 2013_100388 & B405 & $?$ & 2013-10-15 & 2013-11-18 & 2013-11-22 & 34 & 39 & 2 & 2 & 1.0 & NA \\
\hline 2014_100383 & B057 & $\mathrm{F}$ & $2014-10-21$ & 2014-10-21 & 2014-11-12 & 0 & 23 & 23 & 210 & 9.2 & 0.8 \\
\hline 2014_141343 & B244 & $\mathrm{F}$ & 2014-11-04 & 2014-11-06 & 2015-05-01 & 2 & 177 & 131 & 769 & 5.8 & 2.0 \\
\hline 2015_141346 & B186 & $\mathrm{F}$ & $2015-08-30$ & $2015-08-30$ & 2015-09-17 & 0 & 19 & 19 & 149 & 7.8 & 1.7 \\
\hline 2015_106741 & B335 & M & 2015-10-06 & 2015-10-06 & 2015-10-28 & 0 & 23 & 22 & 293 & 13.4 & 1.1 \\
\hline 2015_141344 & B082 & $\mathrm{F}$ & 2015-11-03 & 2015-11-04 & 2015-12-01 & 1 & 29 & 28 & 246 & 8.5 & 1.6 \\
\hline 2015_141349 & B197 & $\mathrm{F}$ & 2015-11-03 & 2015-11-05 & 2016-01-29 & 2 & 85 & 86 & 1145 & 13.2 & 1.1 \\
\hline 2015_141350 & B120 & $\mathrm{M}$ & 2015-11-18 & 2015-11-18 & 2015-12-05 & 0 & 18 & 18 & 118 & 6.6 & 2.0 \\
\hline
\end{tabular}


tagging day until day of last position received) was $88 \mathrm{~d}$ or less for the other PTTs, with a median longevity of $23 \mathrm{~d}$ (Table 1).

Argos Doppler data processed using the Kalman smoothing technique effectively reduced the average ( $\pm \mathrm{SD}$ ) error radius of valid (non-LC Z) blue whale locations compared to the IMM filter $(2.3 \pm 4.7 \mathrm{~km}$ versus $3.3 \pm 8.0 \mathrm{~km}$, respectively). For locations estimated using a low number of messages (1 or 2), the Kalman smoothing technique reduced error radii by approximately $40 \%(4.9 \pm 1.8 \mathrm{~km})$ relative to the IMM filter $(8.4 \pm 3.2 \mathrm{~km})$. However, unlike the latter technique, the tagging location (recorded in the field upon tag deployment) cannot be used to initiate the smoother algorithm. As a result, several tags $(n=4)$ processed with the Kalman smoother ended up with delays to first transmission of 2 to $11 \mathrm{~d}$ longer than with the IMM filter, with 2 tags returning no positions at all. Consequently, we chose to retain IMM-filtered positions for tracks where the initial portion was missing from the Kalman smoothed tracks, with the caveat that these locations may have larger error radii.

Although programmed to transmit continuously, intervals between tag location estimates varied irregularly each day (mean $\pm \mathrm{SD}: 3.1 \pm 6.9 \mathrm{~h}$, median: $1.5 \mathrm{~h}$; Table 1). A total of 4782 valid Argos locations were received from 23 tags, the majority of which were classified as low quality (83\% class B, $8 \%$ class A; see Table S1 in the Supplement). Class B locations were estimated using a mean $\pm \mathrm{SD}$ of $1.2 \pm 0.4$ satellite messages, whereas class A locations were estimated based on $3.0 \pm 0.1$ received messages (higher accuracy). No qualitative relationship was found between tag placement on the body and tag longevity, the number of locations received per day, or location quality (not shown).

A total of 24 tracks from 21 individual blue whales were used for the hSSSM analysis. Per day, 7.3 \pm 3.6 locations were received, corresponding to one location every $2.2 \pm 3.6 \mathrm{~h}$. Based on these results, a $4 \mathrm{~h}$ time step was used to run the hSSSM. Overall, the hSSSM successfully detected 2 distinct movement patterns (or behavioural modes) in the blue whale location data, as implied by the non-overlap of marginal posterior distribution of movement parameter values. Blue whales in transit had mean turning angles $(\theta)$ closer to zero (median $=1.9$ degrees; $95 \%$ credible interval [CI]: $0.5-3.3^{\circ}$ ) and higher autocorrelation in speed and direction $(\gamma)$ compared to blue whales engaged in ARS, which had mean turning angles closer to $180^{\circ}$ (median $=225.9^{\circ} ; 95 \% \mathrm{CI}$ : $199.4-258.8^{\circ}$ ) and lower autocorrelation in move persistence (Fig. 2). Swimming speeds were signifi- cantly lower during ARS behaviour $\left(1.1 \pm 1.0 \mathrm{~km} \mathrm{~h}^{-1}\right)$ than during transiting $\left(5.6 \pm 2.5 \mathrm{~km} \mathrm{~h}^{-1}\right)$ (MannWhitney-Wilcoxon test, $W=80592, \mathrm{p}<0.001)$. Based on hSSSM-derived estimated locations, the distance travelled of tagged whales was $1550 \pm 2657 \mathrm{~km}$ (range 99 to $11918 \mathrm{~km}$ ).

\section{Residency, movements, and model performance}

Short tag longevity (all 3 mo except for one tag), combined with tagging effort concentrated within the SLE and northwestern GSL, resulted in blue whale movement data being restricted spatially
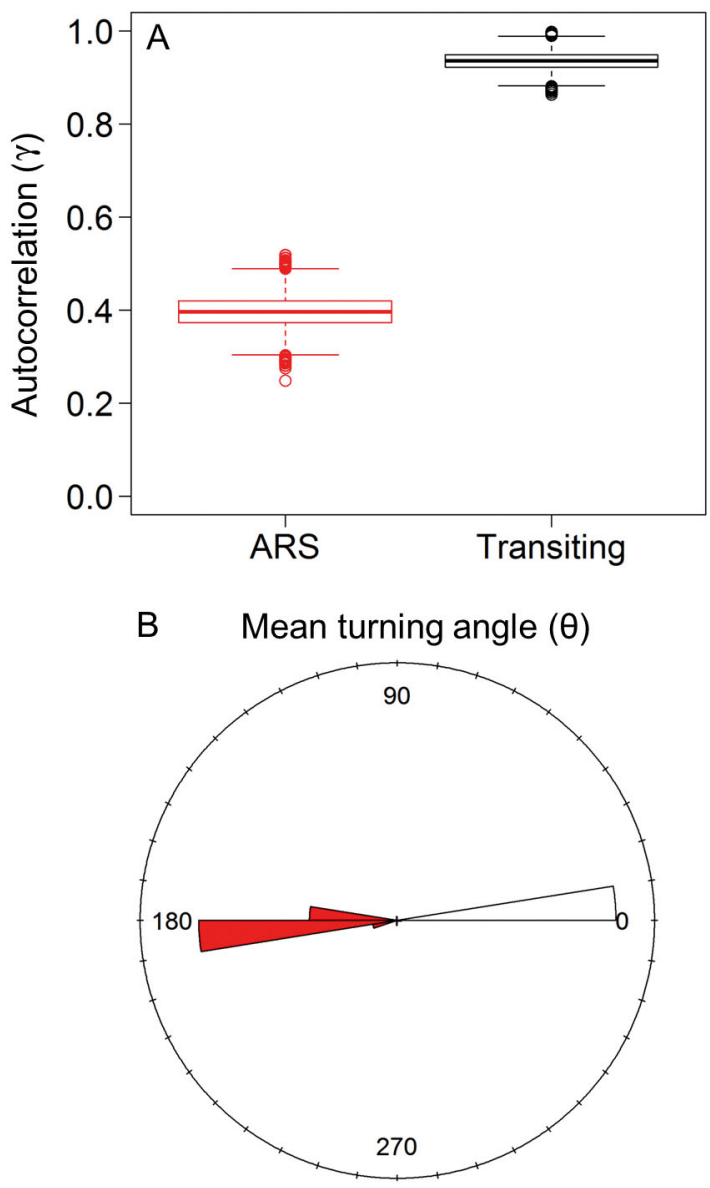

Fig. 2. Distribution of movement parameters used to infer behaviour of blue whales tagged in 2002, and from 2010 to 2015 ( $\mathrm{n}=21$ ). Area-restricted search (ARS) is shown in red and transiting in black. (A) Combined autocorrelation $(\gamma)$ of speed and direction (i.e. move persistence), depicting medians (thick horizontal bars), 25th and 75th percentiles (box), 5th and 95th percentiles (whiskers), and outliers (dots). (B) Mean turning angle $(\theta)$, where the radii of the binned sectors (or length of the 'rose petals') are equal to the square root of the relative frequencies of observations in each sector 
(mainly GSL) and temporally (mainly in the fall) (Fig. 3). However, 2 PTTs transmitted positions for nearly 3 and 6 mo, providing information on migratory routes and areas of use throughout the winter and early spring (Figs. 3 \& 4). Movement patterns for all 23 whales are presented in detail as part of Fig. S1 (in the Supplement at www.int-res.com/articles/ suppl/n034p027_supp.pdf).
Departure date from the SLE and GSL was determined for 10 of the 21 whales tracks analyzed, all of which had initiated migration by 19 December. The remaining 11 whales ceased transmitting prior to departure. Generally, once blue whales left the SLE and northwestern GSL, their direction of travel was southward, with all individuals exiting via Cabot Strait (Fig. 3). Of the 23 tagged whales, only 5 contin-
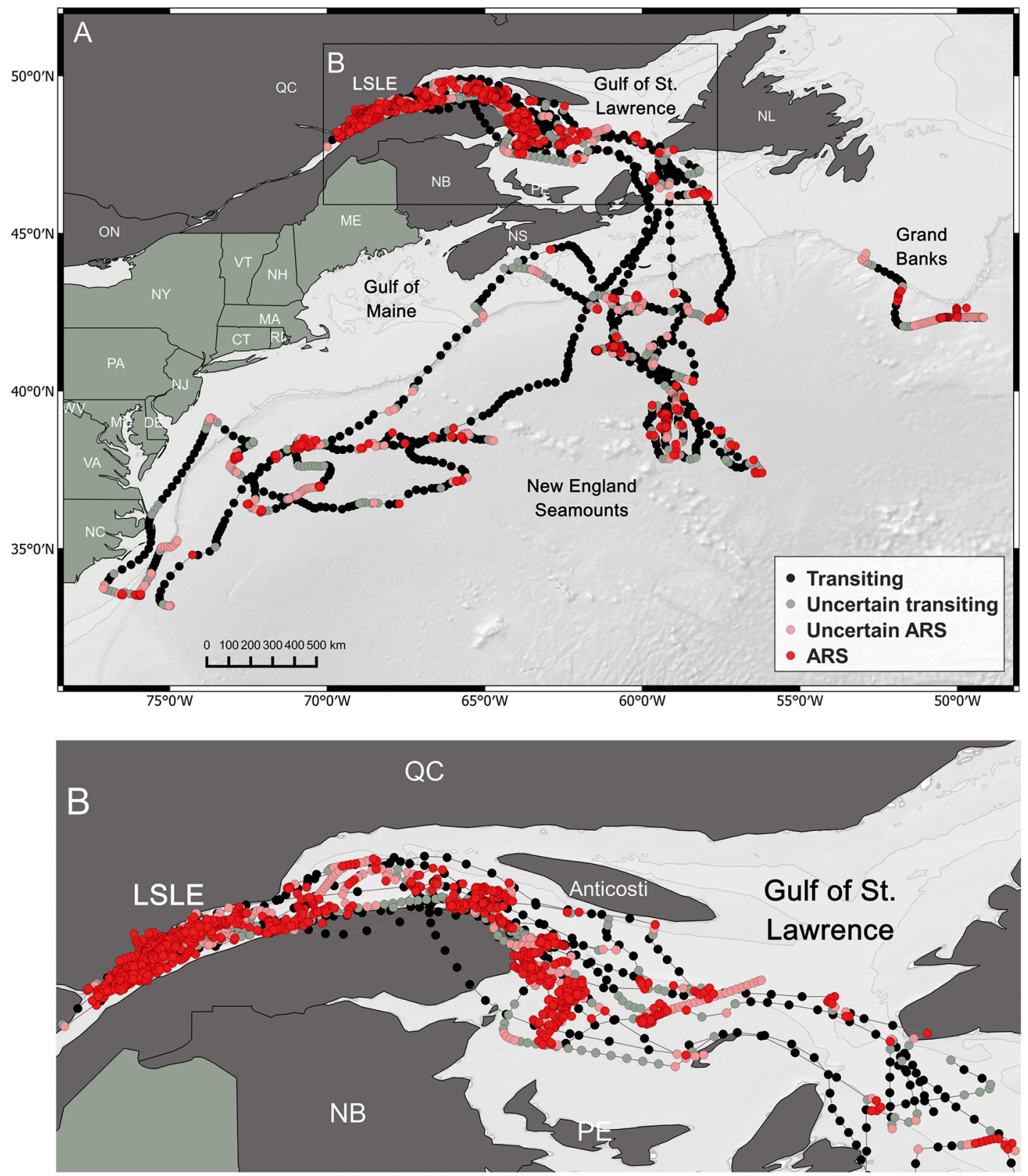

Fig. 3. Switching state-space model location and behaviour estimates for blue whales $(\mathrm{n}=21)$ satellite tagged in 2002 , and from 2010 to 2015. Black circles: transiting behaviour $(b \leq 1.25)$; red circles: ARS behaviour $(b \geq 1.75)$; grey and pink circles: uncertain behaviour with values closer to transiting (grey circles: $b=1.26-1.50$ ) and ARS (pink: $b=1.51-1.74$ ). (A) Entire map of tracks and (B) inset from (A) showing details of the Lower St. Lawrence Estuary (LSLE) and Gulf of St. Lawrence (GSL) 

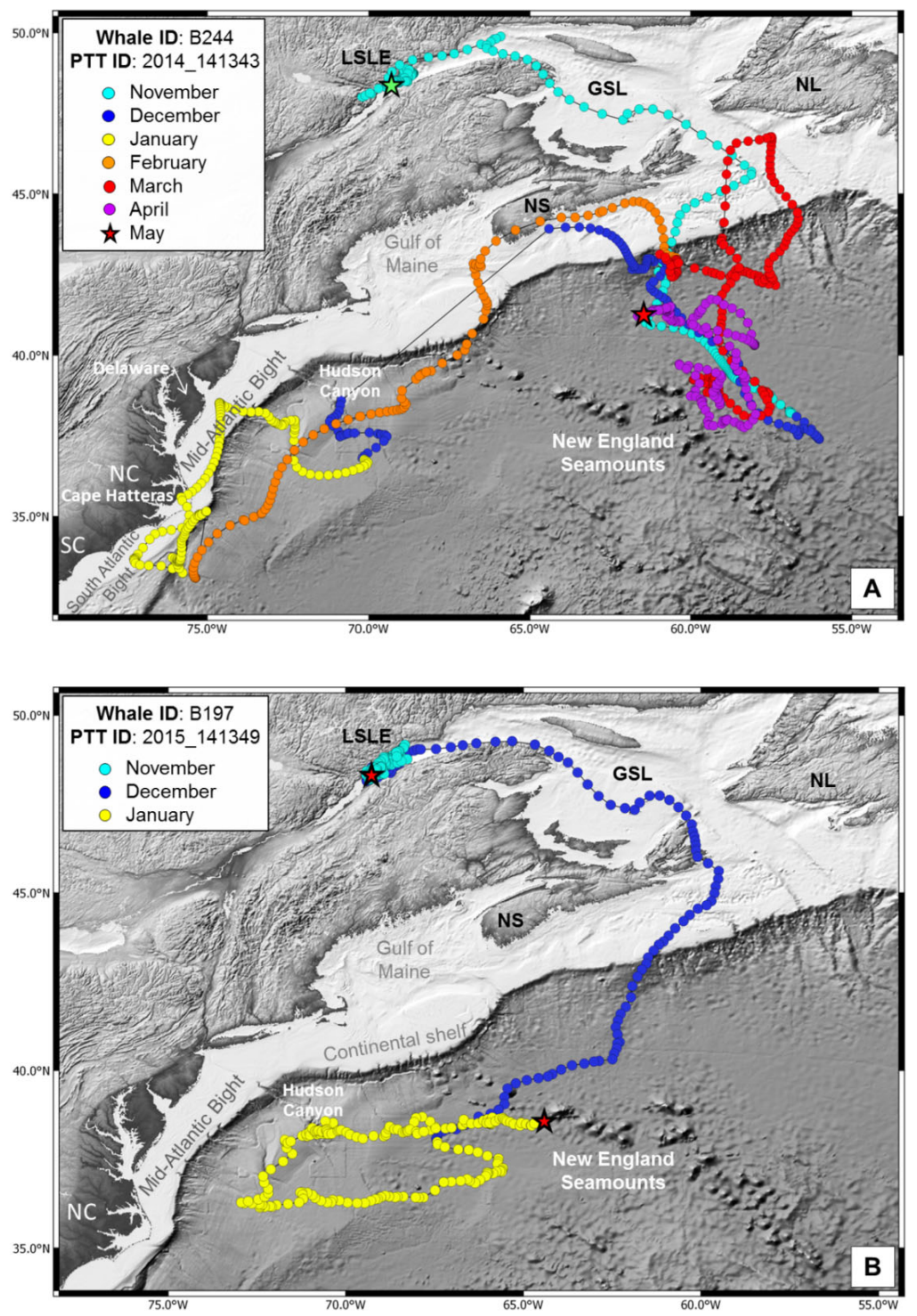

Fig. 4. Switching state-space model estimated positions for 2 female blue whales: (A) whale B244 and (B) whale B197. Stars indicate where tags were deployed in the St. Lawrence Estuary, Canada, and where transmissions ceased in the North Atlantic

ued to transmit positions outside of the SLE and GSL. Movements extended to areas south of Newfoundland (including the Grand Banks), the Scotian Shelf, and the continental shelf edge, where ARS behaviour was documented (Figs. $3 \& 4$ ). Two additional individuals stopped transmitting positions while they were out of the GSL in the Laurentian Channel, but before they could reach the continental shelf edge (Fig. S1).

The fall migration took 2 adult females (B244 and B197) tagged in different years south over the continental shelf off Nova Scotia, and towards offshore areas (depths $>5000 \mathrm{~m}$ ) northeast of the New England Seamount chain (Fig. 4). Both females then proceeded west towards eastern US continental waters. One female (B244) turned around and headed back northeast to within $20 \mathrm{~km}$ of the Nova Scotia coast in mid-December, before reappearing in US continental waters in late December, after a 12-d gap in transmissions.

Between late December and mid-February, movements of these 2 female blue whales were within and offshore of the Mid-Atlantic Bight coastal region (USA) from Delaware to North Carolina (B197) and South Carolina (B244) (Fig. 4). B197 generally remained in deep, offshore waters (hundreds of kilometers from the continental shelf edge) until her last transmission on 30 January 2016. However, this was not the case for B244. This female spent $11 \mathrm{~d}$ in late December about $360 \mathrm{~km}$ east of Delaware in the Mid-Atlantic Bight. In early January, she moved southeast along the edge of the Hudson Canyon (a submarine canyon originating from the Hudson River estuary and extending $640 \mathrm{~km}$ seaward across the continental shelf), and then back northwest along a parallel canyon, all the way to within $40 \mathrm{~km}$ of Delaware Bay. She then headed south along the US east coast, spending some time off Pamlico Sound and Cape Hatteras, North Carolina. In mid-January, B244 moved offshore to the shelf edge, then followed it north to within approximately $45 \mathrm{~km}$ east of Cape Hatteras on January 23. Following $21 \mathrm{~d}$ of silence, the tag re-transmitted locations from the continental shelf, approximately $400 \mathrm{~km}$ east of Charleston, South Carolina - the southernmost location recorded for this female. The return migration followed a northeasterly route located 60 to $200 \mathrm{~km}$ west of the continental shelf edge. Overall, this blue whale spent approximately 2 mo in US waters (midDecember to mid-February), before migrating back to Canadian waters by mid-March. Upon reaching the entrance of the GSL (Cabot Strait), B244 turned around almost immediately, likely due to heavy ice cover remaining in the strait, and returned to areas north of the New England Seamounts until her last transmission on 1 May 2015 (Fig. 4). The total distance covered by this whale during migration was $11918 \mathrm{~km}$. B244 was photographed again in the SLE the following summer (September 2015; R. Roy, contributor to MICS database, unpubl. data). 


\section{Areas of restricted search}

Behavioural inference of blue whale $(\mathrm{n}=21)$ movement data sampled at 4 and $6 \mathrm{~h}$ intervals resulted in a similar proportion of estimated hSSSM locations classified as ARS (52 versus $46 \%$ ), transit (20 versus $22 \%$ ), and uncertain ( 28 versus $31 \%$ ) (3740 and 2498 locations in total, respectively). However, the $4 \mathrm{~h}$ sampling resolution was able to discriminate a greater number of ARS patches compared to the $6 \mathrm{~h}$ time scale ( $\mathrm{n}=100$ versus 83; Fig. 5). Of all blue whale tracks combined in the SLE and GSL, $66 \%$ of estimated hSSSM locations were predicted as ARS behaviour, $10 \%$ were considered transiting, and $24 \%$ were of uncertain behaviour (total no. of loca-
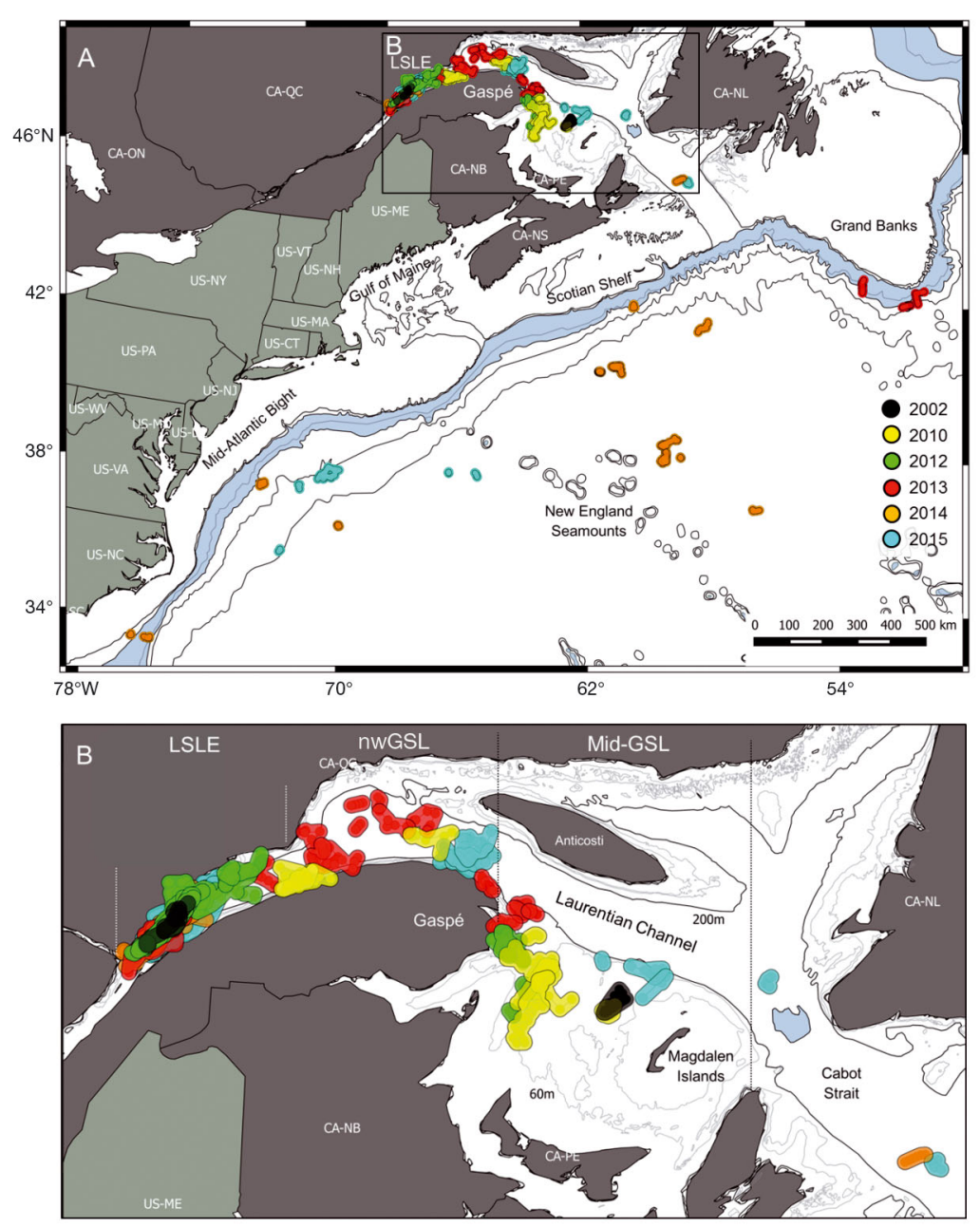

Fig. 5. Area-restricted search (ARS) patches identifed using hSSSMestimated locations inferred at a $4 \mathrm{~h}$ time interval for 21 blue whales in 2002, and from 2010 to 2015. Each ARS patch represents a unique individual which may contribute to several different patches. ARS patches are based on 14 (LSLE); 4 (nwGSL), 11 (mid-GSL) and 4 (outside of the SLE and GSL) individuals. (A) Entire map of tracks and (B) inset from (A) showing details of the Lower St. Lawrence Estuary (LSLE) and Gulf of St. Lawrence (GSL) tions $=2534 ;$ see Fig. S1 for individual hSSSM tracks). Outside of the SLE and GSL, there was a higher proportion of locations classified as transiting (40\%) compared to ARS ( $24 \%$, for $\mathrm{n}=5$ individuals).

When pooling data from tagged whales across years (given the low sample size in some years) and examining predicted behaviour by month, we found that ARS behaviour was predominant between September and November, representing on average 53 to $69 \%$ of blue whale activity. However, the prevalence of ARS behaviour declined to less than $30 \%$ between December and February, while transiting behaviour dominated over ARS during this period, representing 40 to $66 \%$ of blue whale behaviour between December and April (Fig. 6). Bouts of ARS behaviour began increasing again to 36 and $37 \%$ in March and April, respectively. Winter-spring ARS behaviour occurred in proximity to the New England Seamounts, underwater canyons, and the US continental shelf edge (Figs. 3 \& 5). Within the SLE and GSL, females ( $\mathrm{n}=$ 7; not 8 because 1 whale had only $3 \mathrm{~d}$ of data) spent a greater percentage of time $(70 \pm 19 \%)$ in ARS than males $(n=8 ; 53 \pm$ $17 \%)$, although this difference was not significant (Kruskal-Wallis $\chi^{2}=3.43, \mathrm{p}=0.06$ ).

A total of 100 ARS patches were identified from 21 tagged whales, including 47 in the Lower SLE (comprising $\mathrm{n}=14$ individuals), 13 patches in the northwestern GSL (nwGSL; $\mathrm{n}=4), 18$ in the mid-GSL $(\mathrm{n}=11)$, and 22 outside of the SLE and GSL system (n = 4; Fig. 5). In the SLE and GSL, ARS patch area $\left(\mathrm{km}^{2}\right)$ and time spent per ARS patch (days) did not vary significantly with year (Kruskal-Wallis rank sum tests comparing mean time spent within ARS patch between years: $\chi^{2}=2.6, \mathrm{df}=5, \mathrm{p}=0.76$; and mean patch area between years: $\chi^{2}=6.2$, $\mathrm{df}=5, \mathrm{p}=0.29$ ). Years were thus combined for subsequent analyses. There was a significant positive relationship between time spent in an ARS patch (delta_d) and patch area (generalized linear mixed model with random intercepts for 'individual' and a log-linked Gaussian probability distribution; delta_d: $\beta=0.01, \mathrm{SE}=0.01, \mathrm{p}<0.001$ ). The largest ARS patches were located in the Lower SLE $\left(999 \pm 575 \mathrm{~km}^{2}\right.$, median $\left.882 \mathrm{~km}^{2}\right)$ and in the nwGSL $\left(927 \pm 505 \mathrm{~km}^{2}\right.$, median $965 \mathrm{~km}^{2}$ ). Whales spent on average $4.0 \pm 4.1 \mathrm{~d}$ (median $2.7 \mathrm{~d}$ ) per ARS patch in the Lower SLE and $2.5 \pm 2.1 \mathrm{~d}$ (median 


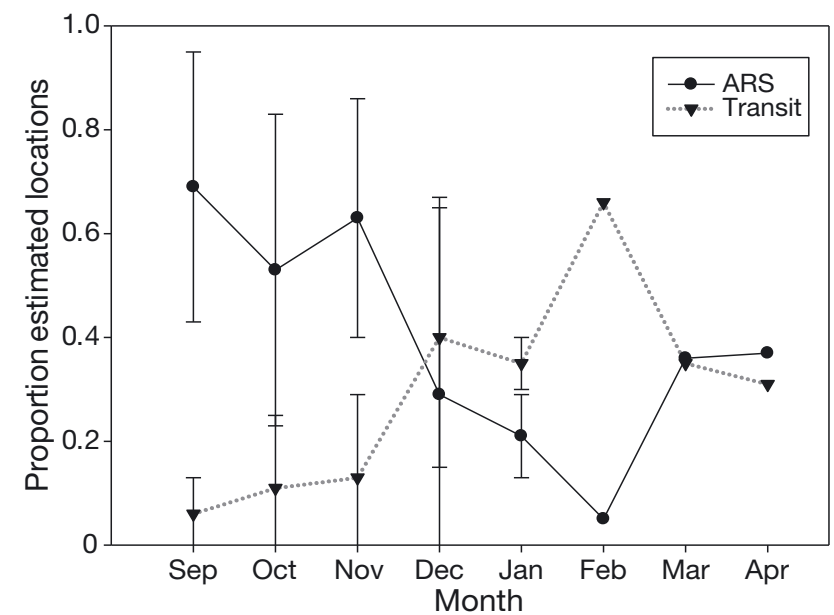

Fig. 6. Seasonal change in the proportion of estimated locations considered as area-restricted search (ARS) and transit behaviour. Error bars are SD

$1.5 \mathrm{~d})$ per patch in the nwGSL. In general, the location of ARS patches in the SLE and GSL overlapped from year to year and between individual whales (Fig. 5).

The majority of ARS patches were located in the Lower SLE, extending from Tadoussac to BaieComeau along the north shore, and from Matane to Ste-Anne-des-Monts along the south shore, including the Anticosti Gyre. Additional ARS patches were located along the north coast of the Gaspé Peninsula east of Rivière-au-Renard (e.g. off Cloridorme and l'Anse-à-Valleau), in the area east and south of the peninsula tip (e.g. American Bank, and north of Bonaventure Island), east of Chaleurs Bay (Orphan Bank and Shediak Valley), as well as $\sim 70 \mathrm{~km}$ northwest of the Magdalen Islands. During the fall period, whales $(n=3)$ engaged in ARS behaviour on the continental shelf edge of the Grand Banks (400-500 km southeast of Newfoundland; $\mathrm{n}=1$ animal), on the Scotian Shelf, and near the New England Seamount chain (400-850 km southeast of Nova Scotia; $\mathrm{n}=1$; Fig. 5). During the winter and spring, ARS patches were scattered in the vicinity of the New England Seamount chain ( $\mathrm{n}=2$ whales), on the slope of the Mid-Atlantic Bight continental shelf $(\mathrm{n}=2)$, and on the slope off South Carolina ( $\mathrm{n}=1$; Fig. 5).

Within the SLE and GSL, there was no trend in time spent within an ARS patch over the course of a season, either when considering all years separately (all adjusted $\mathrm{R}^{2}<0.17$, all $\mathrm{p}>0.08$; with the exception of 2014 [ $n=7$ ]: $R^{2}=0.91, p=0.001$ ) or in combination $\left(\mathrm{R}^{2}=0.0004, \mathrm{p}=0.33\right)$. There was also no significant seasonal trend in ARS patch size $\left(\mathrm{km}^{2}\right)$ either when considering years separately (all $\mathrm{R}^{2}<0.13$, all $\mathrm{p}>$ 0.23 ; with the exception of 2014: $R^{2}=0.61, p=0.024$ ) or in combination $\left(R^{2}=0.03, p=0.85\right)$.

\section{DISCUSSION}

In this study, we report on blue whale movements and habitat use, and infer behaviour using satellitetracked individuals from the western North Atlantic population. We identify several areas of foraging importance for the fall period and transiting corridors within the SLE and GSL in eastern Canada, and provide the first record of migratory movements and winter destinations of 2 female blue whales. As a result of short tag longevity, movement data was largely restricted to the area of tagging effort (SLE and GSL) and to the fall period. There is a need to improve tag attachment technique, while remaining the least invasive possible, if the aim is to study seasonal movements of these cetaceans.

Our results agree with those of previous observational (37 yr; Ramp \& Sears 2013) and radio-telemetry (Doniol-Valcroze et al. 2011) studies, which identified specific areas within the SLE and GSL where blue whales are known to feed during summer. Our satellite-tracked whales remained in some of these areas for extended periods during the fall (up to 18 consecutive days), suggesting that these feeding areas are also used for foraging at that time of the year. Remote tracking also allowed us to locate potential foraging areas which were previously not described for this population (since offshore habitats are rarely sampled). These include some areas located several tens of kilometers off the Gaspé Peninsula and Chaleurs Bay in the GSL (Orphan Bank, Shediak Valley or north of the Magdalen Islands), as well as sectors distributed along the continental shelf edge off Nova Scotia and the Grand Banks.

Blue whales feed almost exclusively on euphausiids (krill), although they may occasionally consume copepods (Kawamura 1980). In the SLE and GSL, the large-scale physical and biological processes contributing to the formation of dense krill aggregations are relatively well understood (Sameoto 1976, Simard et al. 1986, Maps et al. 2015, Plourde et al. 2014, Lavoie et al. 2015, McQuinn et al. 2015). Topographic forcing of surface circulation in areas with steep slopes is a habitat feature often associated with krill aggregations (e.g. Sameoto 1976, Simard et al. 1986, Genin 2004, Croll et al. 2005, Maps et al. 2015, McQuinn et al. 2015). Additional factors, such as currents and the diel vertical migration of krill, may also lead to convergence of krill in areas that are not necessarily along slopes (Maps et al. 2015). This was illustrated by a study using a blue whale presenceonly habitat model, which identified topographical 
heterogeneity as an important variable explaining foraging blue whale distribution in the SLE. Blue whales exploited slope areas, as well as plateaus and deep areas over flat beds as feeding habitat at certain periods of the tidal cycle (Doniol-Valcroze et al. 2012). In general, there was strong agreement between areas we identified based on blue whale ARS behaviour (Fig. 5) and those where recurrent krill aggregations have been observed or predicted to be substantial in eastern Canada. These include several areas along the slope of the Laurentian Channel, the continental shelf edge, and sectors within shelf habitats (depth $<100 \mathrm{~m}$ ) of the SLE and GSL (Simard \& Lavoie 1999, Lavoie et al. 2000, Sourisseau et al. 2006, McQuinn et al. 2015, Plourde et al. 2016).

The classical depiction of the annual cycle of capital breeding mysticetes involves alternating feast and famine as the animals move from their feeding to breeding areas (Lockyer \& Brown 1981, Clapham 1996; although see exceptions in Geijer et al. 2016). However, migrating animals likely encounter zones of heightened productivity in the open ocean, where intermittent feeding may occur during winter and spring (Silva et al. 2013). Whether the ARS behaviour we documented from 2 female blue whales during the winter (Figs. $3 \& 5$ ) reflected foraging or another behaviour with a similar movement structure (slow displacement and high turning angles; Bailey et al. 2008) is unknown. However, the association of ARS with marked topographical features known to characterize blue whale foraging habitat such as submarine canyons and continental shelf edge, i.e. slope structures that can induce upwelling and enhanced productivity, suggests that the documented ARS probably reflected foraging activity in these regions. Whether the one female (B244) that spent a month (January-February) near and offshore the Cape Hatteras region in North Carolina was engaged in reproductive activities, foraging, or both is uncertain. There is a distinct biogeographic boundary in the Cape region, where the 2 great basins of the western Atlantic converge and the south-flowing Labrador Current meets the northwest-flowing Gulf Stream, creating an abrupt latitudinal shift in water temperature (Cerame-Vivas \& Gray 1966). The ensuing mixing of water masses favors primary production (Lohrenz et al. 2002) and supports a diverse biological assemblage (Colvocoresses \& Musick 1984, Sherman et al. 1998, Cook \& Auster 2007, Gartner et al. 2008). This diversity includes numerous cetacean species within the Cape Hatteras region (Hamazaki 2002, Schick et al. 2011) which peak in abundance around springtime (Hain et al. 1985). Minke whales
Balaenoptera acutorostrata, in the same family as blue whales, have been detected acoustically in the southeastern US continental shelf edge region during the winter months and are suspected to use this area for calving (Risch et al. 2014).

The prolonged stints of blue whale ARS behaviour, near the New England Seamount chain, both in the fall and in the spring, are noteworthy. ARS associated with calving or mating would be expected to occur mainly in late fall or early winter and be restricted to a month or two; however, ARS in this region was observed both in the fall and spring. The use of seamount habitats by some air-breathing vertebrates including marine mammals has been shown in a number of studies (e.g. Kaschner 2008, Garrigue et al. 2015). Sperm whale vocalizations have been recorded around one of the New England Seamounts (Kelvin Seamount) from November to June (Wong \& Whitehead 2014), and a satellite-tracked humpback whale demonstrated ARS behaviour south of the seamount chain during its northbound migration from the Antilles breeding ground (Kennedy et al. 2014). We know little about the productivity and biodiversity of the New England Seamounts (a 1000$\mathrm{km}$-long extinct volcanic range; Worm et al. 2003) and to what spatial extent this 'underwater island system' influences blue whale behaviour. The imposing Gulf Stream current sweeps over this area, circulating from southwest to northeast (Hogg 1992); this could push local productivity to the east or northeast of the seamounts. Certain sites of blue whale ARS behaviour were located in this region but at several tens of kilometers from these deep-ocean structures. Morato et al. (2010) showed that pelagic species diversity remains high for up to $40 \mathrm{~km}$ from seamount summits. There is likely considerable spatial and temporal variation in habitats surrounding the seamounts, influenced by depth, topography, and current regimes (Kvile et al. 2014). Some authors predict a higher degree of bentho-pelagic trophic transfer, enhanced productivity, and a greater numbers of endemic species near oceanic seamount structures (Pitcher et al. 2007, Kvile et al. 2014). Dedicated winter/spring surveys over the New England Seamounts would help elucidate the degree of marine mammal biodiversity in this offshore region.

Increasing evidence suggests that baleen whales may take advantage of locally abundant food resources outside their typical foraging grounds (e.g. Reilly \& Thayer 1990, Mate et al. 1999, Visser et al. 2011, Silva et al. 2013, Owen et al. 2015). A closer look at seasonal movements within and across baleen whale populations has revealed that dynamic 
migration strategies do not conform with a feast and famine yearly cycle (Geijer et al. 2016). For instance, blue whales in the northeastern Pacific exhibit ARS behaviour throughout the migratory cycle (Bailey et al. 2009). Two satellite-tracked blue whales in the Northeast Atlantic appeared to use the Azores as a stopover site, possibly for feeding, during their spring northbound migration (Silva et al. 2013). Feeding opportunities during the return journey to feeding grounds are undoubtedly valuable, particularly if energy reserves are running low as a result of breeding and/or nursing (e.g. Best et al. 1995, Visser et al. 2011, Silva et al. 2013). Whales may also use major current systems to reduce energy expenditure during long migrations. For example, the one female tracked over her near-complete migration returned north within the Gulf Stream, which can have a maximum velocity of around $9 \mathrm{~km} \mathrm{~h}^{-1}$ flowing northeasterly (average $6.4 \mathrm{~km} \mathrm{~h}^{-1}$ ) (NOAA 2014). Using this current to aid in the direction of travel likely reduced energy expenditure before reaching summer feeding grounds.

Another aspect to consider when studying seasonal habitat is that not all individuals or populations migrate (Geijer et al. 2016). Habitat requirements are poorly understood for blue whales, but likely vary according to energy requirements, which may depend on age, sex, size, and reproductive state (Corkeron \& Connor 1999, Ford \& Reeves 2008). Blue whale sighting, acoustic and telemetry data in other regions indicate that some areas may be used year-round, with a portion of the population remaining in productive waters during the breeding season, or in breeding waters during the feeding period (Kellogg 1929, Reilly \& Thayer 1990, Šrović et al. 2004, Branch et al. 2007, Bailey et al. 2009). In our study, all 7 tagged whales that exited the GSL showed a uniform, southerly movement. However, whether blue whale seasonal movements in the western North Atlantic represent complete migration (cyclical, predictable, round-trip movement of the entire population), partial migration (only a fraction of the population migrates), or differential migration (migration strategy varies depending on age, sex, or reproductive status) is unknown (Geijer et al. 2016). As for most marine mammals, blue whale distribution is likely dictated by key drivers such as food requirements and availability, sea ice, reproduction, and predation risks. Data on blue whale occurrence in eastern Canadian waters outside the ice-free period are scarce. Anecdotal sightings of blue whales have been reported in the SLE and northern GSL in January, a period where whales run the risk of ice entrap- ment in the seasonally ice-covered region (Sears \& Calambokidis 2002; Group of Research and Education on Marine Mammals, Tadoussac, Québec, unpubl. data). Other potential winter feeding areas at higher latitudes include areas south of Nova Scotia and Newfoundland, including the Grand Banks, which remain relatively ice-free throughout winter. Blue whale calls have been detected on the Grand Banks during the winter months (Clark 1995). There are also regular reports of ice-entrapped blue whales in March and April along the southeast coast of Newfoundland, near the entrance to the GSL (Sergeant 1982, Stenson et al. 2003; J. Lawson, DFO Newfoundland, unpubl. data). However, these may have been animals returning to the GSL after overwintering elsewhere (as was the case for our tagged blue whale B244).

Prior to this study, there was limited information on the presence of blue whales at southern latitudes in winter. One blue whale had been tracked acoustically from the Newfoundland-Labrador region south past Bermuda and into the West Indies using hydrophone arrays from the US Navy's Integrated Undersea Surveillance System (Clark 1995). Other data suggesting occupancy of southern latitudes during the winter in the western North Atlantic include rare anecdotal sightings, and catch (or attempted catch) data extracted from 18th and 19th century whaling logbooks (Reeves et al. 2004). The 2 females we tracked to an area of warm and deep oceanic waters located in the Mid-Atlantic Bight off the US coast provide insight into what may constitute part of the wintering area for blue whales in the western North Atlantic (Fig. 5). Movement towards subtropical, warmer waters for breeding or calving may reduce energy expenditure of newborn calves, and of fasting and nursing mothers, as well as reduce risk of ice entrapment (Corkeron \& Connor 1999). Whether the areas these females visited were used for reproductive purposes could have been clarified had we known their reproductive status. The fact that transiting was the predominant behaviour of both females while at southern latitudes suggests that wintering areas may be relatively diffuse. The observed occupancy of offshore waters and few incursions into coastal waters during winter, if typical of other individuals in the population, could explain why blue whale winter distribution in the western North Atlantic is poorly understood.

In summary, our blue whale movement results, combined with prior knowledge of their seasonal occurrence, emphasize the wide home range of this population in the western North Atlantic, and the 
vast scale (i.e. many thousands of square kilometers) one needs to consider when addressing conservation issues related to this population. Our data indicate that there is likely a strong connectivity among blue whale areas of concentration at northern latitudes, with fall movements documented between the SLE and several areas in the northwestern GSL, southern Newfoundland, the Grand Banks, and the Scotian Shelf (Fig. 3). Cabot Strait appears to be the main corridor for movements in and out of the GSL, and Honguedo Strait (between Gaspé Peninsula and Anticosti Island) represents the principal transit area between the northwestern GSL and SLE. Our study contributes valuable knowledge about foraging locations, migratory patterns, and winter destinations of this endangered population, and suggests sporadic foraging outside the feeding season. The results also highlight that seamounts and other deep ocean structures are potentially important habitat for blue whales. According to Canadian legislation, the Critical Habitat of western North Atlantic blue whales and its characteristics must be defined and protected, so that vital life history processes that depend on this habitat remain intact. This study demonstrates that blue whales frequent areas outside of Canadian waters, which may serve important foraging, reproductive, or resting functions. Future research efforts are encouraged to hone in on areas we identified to investigate their role and importance in the annual cycle of this blue whale population. International efforts will likely be required to better characterize areas of recurrent use and to ensure the conservation of this endangered population.

Acknowledgements. We thank Y. Morin, D. Gaspard, A. Mosnier, T. Doniol-Valcroze, F. Paquet, J. Lawson, M. Guilpin, S. Turgeon, A. Borowicz, and R. Sullivan-Lord for help with fieldwork, and R. Roy for communicating information on blue whale sightings. We also thank J. Lemire and the crew of the 'Sedna IV' for their dedication in trying to find blue whales in remote areas. We are also grateful to I. Jonsen for his guidance on hSSSM implementation and interpretation. This study was supported by the Species at Risk Research Program of Fisheries and Oceans Canada, and by Margo Walker, the Canadian Whale Institute (Sara Haney), Sue Smith, Nick Huber Guitars, and Glacialis Productions through sponsorship of the Mingan Island Cetacean Study (MICS) organization.

\section{LITERATURE CITED}

Andrews RD, Pitman RL, Ballance LT (2008) Satellite tracking reveals distinct movement patterns for Type B and Type C killer whales in the southern Ross Sea, Antarctica. Polar Biol 31:1461-1468
Austin D, McMillan JI, Bowen WD (2003) A three-stage algorithm for filtering erroneous Argos satellite locations. Mar Mamm Sci 19:371-383

* Bailey H, Shillinger G, Palacios D, Bograd S, Spotila J, Paladino F, Block B (2008) Identifying and comparing phases of movement by leatherback turtles using statespace models. J Exp Mar Biol Ecol 356:128-135

Bailey H, Mate BR, Palacios DM, Irvine L, Bograd SJ, Costa DP (2009) Behavioural estimation of blue whale movements in the Northeast Pacific from state-space model analysis of satellite tracks. Endang Species Res 10: 93-106

Balmer BC, Wells RS, Howle LE, Barleycorn AA and others (2014) Advances in cetacean telemetry: a review of single pin transmitter attachment techniques on small cetaceans and development of a new satellite-linked transmitter design. Mar Mamm Sci 30:656-673

Best PB, Sekiguchi K, Findlay KP (1995) A suspended migration of humpback whales Megaptera novaeangliae on the west coast of South Africa. Mar Ecol Prog Ser 118: $1-12$

Best PB, Mate B (2007) Sighting history and observations of southern right whales following satellite tagging off South Africa. J Cetacean Res Manag 9:111-114

* Branch TA, Stafford KM, Palacios DM, Allison C, and others (2007) Past and present distribution, densities and movements of blue whales Balaenoptera musculus in the southern hemisphere and northern Indian Ocean. Mammal Rev 37:116-175

Cerame-Vivas MJ, Gray IE (1966) The distributional pattern of benthic invertebrates of the continental shelf off North Carolina. Ecology 47:260-270

Clapham PJ (1996) The social and reproductive biology of humpback whales: an ecological perspective. Mammal Rev 26:27-49

Clark CW (1995) Application of US Navy underwater hydrophone arrays for scientific research on whales. Rep Int Whaling Comm 45:210-212

Colvocoresses JA, Musick JA (1984) Species associations and community composition of Middle Atlantic Bight continental shelf demersal fishes. Fish Bull 82:295-313

Cook RR, Auster PJ (2007) A bioregional classification of the continental shelf of northeastern North America for conservation analysis and planning based on representation. Marine Sanctuaries Conservation Series NMSP-07-03. US Department of Commerce, National Oceanic and Atmospheric Administration, National Marine Sanctuary Program, Silver Spring, MD

Corkeron PJ, Connor RC (1999) Why do baleen whales migrate? Mar Mamm Sci 15:1228-1245

Croll DA, Marinovic B, Benson S, Chavez FP, Black N, Ternullo R, Tershy BR (2005) From wind to whales: trophic links in a coastal upwelling system. Mar Ecol Prog Ser 289:117-130

Curio E (1976) The ethology of predation. Springer-Verlag, New York, NY

Desbrosse A, Etcheberry R (1987) Marine mammals of St. Pierre and Miquelon. Osprey 18:125-137

* Dirzo R, Young HS, Galetti M, Ceballos G, Isaac NJB, Collen B (2014) Defaunation in the Anthropocene. Science 345: 401-406

Doniol-Valcroze T, Berteaux D, Larouche P, Sears R (2007) Influence of thermal fronts on habitat selection by four rorqual whale species in the Gulf of St. Lawrence. Mar Ecol Prog Ser 335:207-216 
Doniol-Valcroze T, Lesage V, Giard J, Michaud R (2011) Optimal foraging theory predicts diving and feeding strategies of the largest marine predator. Behav Ecol 22: 880-888

Doniol-Valcroze T, Lesage V, Giard J, Michaud R (2012) Challenges in marine mammal habitat modelling: evidence of multiple foraging habitats from the identification of feeding events in blue whales. Endang Species Res 17:255-268

Donovan G (1991) A review of IWC stock boundaries. Rep Int Whaling Comm Spec Issue13:39-68

Double MC, Andrews-Goff V, Jenner KCS, Jenner MN, Laverick SM, Branch TA, Gales NJ (2014) Migratory movements of pygmy blue whales (Balaenoptera muscuIus brevicauda) between Australia and Indonesia as revealed by satellite telemetry. PLOS ONE 9:e93578

Fiedler PC, Reilly SB, Hewitt RP, Demer D and others (1998) Blue whale habitat and prey in the California Channel Islands. Deep Sea Res II 45:1781-1801

Ford JKB, Reeves RR (2008) Fight or flight: antipredator strategies of baleen whales. Mammal Rev 38:50-86

* Gardner RH, O'Neill RV, Turner MG, Dale VH (1989) Quantifying scale-dependent effects of animal movement with simple percolation models. Landsc Ecol 3:217-227

Garrigue C, Clapham PJ, Geyer Y, Kennedy AS, Zerbini AN (2015) Satellite tracking reveals novel migratory patterns and the importance of seamounts for endangered South Pacific humpback whales. R Soc Open Sci 2:150489

Gartner JV Jr, Sulak KJ, Ross SW, Necaise AM (2008) Persistent near-bottom aggregations of mesopelagic animals along the North Carolina and Virginia continental slopes. Mar Biol 153:825-841

Geijer CKA, Notarbartolo di Scara G, Panigada S (2016) Mysticete migration revisited: Are Mediterranean fin whales an anomaly? Mamm Rev 46:284-296

Gendron D, Martinez Serrano I, Ugalde de la Cruz A, Calambokidis J, Mate B (2015) Long-term individual sighting history database: an effective tool to monitor satellite tag effects on cetaceans. Endang Species Res 26: 235-241

Genin A (2004) Bio-physical coupling in the formation of zooplankton and fi sh aggregations over abrupt topographies. J Mar Syst 50:3-20

Hain JH, Hyman MA, Kenney RD, Winn HE (1985) The role of cetaceans in the shelf-edge region of the northeastern United States. Mar Fish Rev 47:13-17

*Hamazaki T (2002) Spatiotemporal prediction models of cetacean habitats in the mid-western North Atlantic Ocean (from Cape Hatteras, North Carolina, USA to Nova Scotia, Canada). Mar Mamm Sci 18:920-939

*Hazen EL, Maxwell SM, Bailey H, Bograd SJ and others (2012) Ontogeny in marine tagging and tracking science: technologies and data gaps. Mar Ecol Prog Ser 457: 221-240

* Hoenner X, Whiting SD, Hindell MA, McMahon CR (2012) Enhancing the use of Argos satellite data for home range and long distance migration studies of marine animals. PLOS ONE 7:e40713

Hogg NG (1992) On the transport of the Gulf Stream between Cape Hatteras and the Grand Banks. Deep Sea Res A 39:1231-1246

Houston AI, Stephens PA, Boyd IL, Harding KC, McNamara JM (2007) Capital or income breeding? A theoretical model of female reproductive strategies. Behav Ecol 18: 241-250
Hussey NE, Kessel ST, Aarestrup K, Cooke SJ and others (2015) Aquatic animal telemetry: a panoramic window into the underwater world. Science 348:1255462

Ingebrigtsen A (1929) Whales caught in the North Atlantic and other seas. Rapp P-V Réun Cons Perm Int Explor Mer 56:3-26

Jonsen ID, Myers RA, Mills Flemming J (2003) Meta-analysis of animal movement using state-space models. Ecology 84:3055-3063

Jonsen ID, Mills Flemming J, Myers RA (2005) Robust statespace modeling of animal movement data. Ecology 86: 2874-2880

Jonsen ID, Myers RA, James MC (2006) Robust hierarchical state-space models reveal diel variation in travel rates of migrating leatherback turtles. J Anim Ecol 75:1046-1057

Jonsen ID, Myers RA, James MC (2007) Identifying leatherback turtle foraging behaviour from satellite telemetry using a switching state-space model. Mar Ecol Prog Ser 337:255-264

Jonsen ID, Basson M, Bestley S, Bravington MV and others (2013) State-space models for bio-loggers: a methodological road map. Deep Sea Res II 88-89:34-46

Jonsgård A (1955) The stocks of blue whales (Balaenoptera musculus) in the Northern Atlantic ocean and adjacent Arctic waters. Nor Hvalfangst-Tid 9:297-311

Kareiva P, Odell G (1987) Swarms of predators exhibit 'preytaxis' if individual predators use area-restricted search. Am Nat 130:233-270

Kaschner K (2008) Air-breathing visitors to seamounts: marine mammals. In: Pitcher TJ, Morato T, Hart PJB, Clark MR, Haggan N, Santos RS (eds) Seamounts: ecology, conservation and management. Fish and Aquatic Resources Series 12. Blackwell, Oxford, p 230-238

Kawamura A (1980) A review of food of balaenopterid whales. Sci Rep Whales Res Inst 32:155-170

Kellogg R (1929) What is known of the migrations of some of the whalebone whales. Annu Rep Board Regents Smithson Inst 1928:467-494

*Kennedy AS, Zerbini AN, Vásquez OV, Gandilhon N, Clapham PJ, Adam O (2014) Local and migratory movements of humpback whales (Megaptera novaeangliae) satellite-tracked in the North Atlantic Ocean. Can J Zool 92:9-18

Kvile KØ, Taranto GH, Pitcher TJ, Morato T (2014) A globl assessment of seamount ecosystems knowledge using an ecosystem evaluation framework. Biol Conserv 173: 108-120

Lavoie D, Simard Y, Saucier FJ (2000) Aggregation and dispersion of krill at channel heads and shelf edges: the dynamics in the Saguenay-St. Lawrence Marine Park. Can J Fish Aquat Sci 57:1853-1869

Lavoie D, Chassé J, Simard Y, Lambert N, Galbraith PS, Roy N, Brickman D (2016) Large-scale atmospheric and oceanic control on krill transport into the St. Lawrence Estuary evidenced with three-dimensional numerical modelling. Atmos-ocean 54:1-27

Lockyer CHL, Brown SG (1981) The migration of whales. In: Aidley DJ (ed) Animal migration. Cambridge University Press, Cambridge, p 105-138

Lohrenz SE, Redalje DG, Verity PG, Flagg CN, Matulewski KV (2002) Primary production on the continental shelf off Cape Hatteras, North Carolina. Deep Sea Res II 49: 4479-4509

* Lopez R, Malarde JP, Royer F, Gaspar P (2014) Improving Argos Doppler location using multiple-model Kalman 
filtering. IEEE Trans Geosci Remote Sens 52:4744-4755

Lopez R, Malarde JP, Danès P, Gaspar P (2015) Improving Argos Doppler location using multiple-model smoothing. Anim Biotelem 3:32

Lowther AD, Lydersen C, Fedak MA, Lovell P, Kovacs KM (2015) The Argos-CLS Kalman filter: error structures and state-space modelling relative to Fastloc GPS data. PLOS ONE 10:e0124754

Maps F, Plourde S, McQuinn IH, St-Onge-Drouin S, Lavoie D, Chassé J, Lesage V (2015) Linking acoustics and finite-time Lyapunov exponents (FTLE) reveals areas and mechanisms of krill aggregation within the Gulf of St. Lawrence, eastern Canada. Limnol Oceanogr 60: 1965-1975

Mate BR, Lagerquist BA, Calambokidis J (1999) Movements of North Pacific blue whales during the feeding season off southern California and their southern fall migration. Mar Mamm Sci 15:1246-1257

Mate B, Mesecar R, Lagerquist B (2007) The evolution of satellite-monitored radio-tags for large whales: one laboratory's experiment. Deep Sea Res II 54:224-247

* McQuinn IH, Plourde S, St-Pierre JF, Dion M (2015) Spatial and temporal variations in the abundance, distribution, and aggregation of krill (Thysanoessa raschii and Meganyctiphanes norvegica) in the lower estuary and Gulf of St. Lawrence. Prog Oceanogr 131:159-176

Mills Flemming J, Jonsen ID, Myers RA, Field CA (2010) Hierarchical state-space estimation of leatherback turtle navigation ability. PLOS ONE 5:e14245

Morales JM, Haydon DT, Friar J, Holsinger KE, Fryxell JM (2004) Extracting more out of relocation data: building movement models as mixtures of random walks. Ecology 85:2436-2445

Morato T, Hoyle SD, Allain V, Nicol SJ (2010) Seamounts are hotspots of pelagic biodiversity in the open ocean. Proc Natl Acad Sci USA 107:9707-9711

Nieukirk SL, Stafford KM, Mellinger DK, Dziak RP, Fox CG (2004) Low-frequency whale and seismic airgun sounds recorded in the mid-Atlantic Ocean. J Acoust Soc Am 115:1832-1843

NOAA (National Oceanic and Atmospheric Administration) (2014) How fast is the Gulf Stream? http://oceanservice. noaa.gov/facts/gulfstreamspeed.html (accessed 10 March 2015)

Norris K (1967) Some observations on the migration of marine mammals. In: Storm RN (ed) Animal orientation and navigation. University of California Press, Berkeley, CA, p 320-380

Kowen K, Warren JD, Noad MJ, Donnelly D, Goldizen AW, Dunlop RA (2015) Effect of prey type on the fine-scale feeding behaviour of migrating east Australian humpback whales. Mar Ecol Prog Ser 541:231-244

Patterson TA, Thomas L, Wilcox C, Ovaskainen O, Matthiopoulos J (2008) State-space models of individual animal movement. Trends Ecol Evol 23:87-94

Pitcher TJ, Morato T, Hart PJB, Clark MR, Haggan N, Santos RS (eds) (2007) Seamounts: ecology, conservation and management. Fish and Aquatic Resources Series 12. Blackwell, Oxford

* Plourde S, McQuinn IH, Maps F, St-Pierre JF, Lavoie D, Joly P (2014) Daytime depth and thermal habitat of two sympatric krill species in response to surface salinity variability in the Gulf of St Lawrence, eastern Canada. ICES J Mar Sci 71:272-281

*PPlourde S, Lehoux C, McQuinn IH, Lesage V (2016) Model- ling krill distribution in the Northwest Atlantic using statistical habitat models. DFO Can Sci Advis Sec Res Doc 2016/nnn. www.dfo-mpo.gc.ca/csas

* Prieto R, Silva MA, Waring GT, Gonçalves JMA (2014) Sei whale movements and behaviour in the North Atlantic inferred from satellite telemetry. Endang Species Res 26: 103-113

Kamp C, Sears R (2013) Distribution, densities, and annual occurrence of individual blue whales (Balaenoptera musculus) in the Gulf of St. Lawrence, Canada from 1980-2008. DFO Can Sci Advis Sec Res Doc 2012/157. www.dfo-mpo.gc.ca/csas

Keeves RR, Smith TD, Josephson EA, Clapham PJ, Woolmer G (2004) Historical observations of humpback and blue whales in the North Atlantic Ocean: clues to migratory routes and possibly additional feeding grounds. Mar Mamm Sci 20:774-786

* Reilly SB, Thayer VG (1990) Blue whale (Balaenoptera musculus) distribution in the eastern tropical Pacific. Mar Mamm Sci 6:265-277

Rice DW (1998) Marine mammals of the world: systematics and distribution. Mar Mamm Sci Spec. Publ. 4

Risch D, Castellote M, Clark CW, Davis GE and others (2014) Seasonal migrations of North Atlantic minke whales: novel insights from large-scale passive acoustic monitoring networks. Mov Ecol 2:24

* Robbins J, Zerbini AN, Gales N, Gulland FMD and others (2013) Satellite tag effectiveness and impacts on large whales: preliminary results of a case study with Gulf of Maine humpback whales. Report SC/65a/SH05 presented to the International Whaling Commission Scientific Committe, Jeju, Korea. www.marinemammals.gov.au/_data/ assets/pdf_file/0018/135612/SC-65a-SH05.pdf

* Sameoto DD (1976) Distribution of sound scattering layers caused by euphausiids and their relationship to chlorophyll a concentrations in the Gulf of St. Lawrence estuary. J Fish Res Board Can 33:681-687

Schick RS, Halpin PN, Read AJ, Urban DL and others (2011) Community structure in pelagic marine mammals at large spatial scales. Mar Ecol Prog Ser 434:165-181

* Schoenherr JR (1991) Blue whales feeding on high concentrations of euphausiids around Monterey submarine canyon. Can J Zool 69:583-594

Sears R, Calambokidis J (2002) Update COSEWIC status report on the blue whale, Balaenoptera musculus, in Canada. In: COSEWIC assessment and update status report on the blue whale, Balaenoptera musculus, in Canada. Committee on the Status of Endangered Wildlife in Canada, Ottawa, p 1-32

Sears R, Larsen F (2002) Long range movements of a blue whale (Balaenoptera musculus) between the Gulf of St. Lawrence and West Greenland. Mar Mamm Sci 18: 281-285

Sears R, Williamson JM, Wenzel FW, Bérubé M, Gendron D, Jones P (1990) Photographic identification of the blue whale (Balaenoptera musculus) in the Gulf of St. Lawrence, Canada. Rep Int Whaling Comm Spec Issue 12:335-341

Sergeant DE (1982) Some biological correlates of environmental conditions around Newfoundland during 197079: harp seals, blue whales, and fulmar petrels. NAFO Sci Counc Stud 5:107-110

* Sherman K, Solow A, Jossi J, Kane J (1998) Biodiversity and abundance of the zooplankton of the Northeast Shelf ecosystem. ICES J Mar Sci 55:730-738 
Silva MA, Prieto R, Jonsen I, Baumgartner MF, Santos RS (2013) North Atlantic blue and fin whales suspend their spring migration to forage in middle latitudes: building up energy reserves for the journey? PLOS ONE 8: e76507

Silva MA, Jonsen I, Russell DJF, Prieto R, Thompson D, Baumgartner MF (2014) Assessing performance of Bayesian state-space models fit to Argos satellite telemetry locations processed with Kalman filtering. PLOS ONE 9:e92277

Simard Y, Lavoie D (1999) The rich krill aggregation of the Saguenay - St. Lawrence Marine Park: hydroacoustic and geostatistical biomass estimates, structure, variability, and significance for whales. Can J Fish Aquat Sci 56: 1182-1197

Simard Y, de Ladurantaye R, Therriault JC (1986) Aggregation of euphausiids along a coastal shelf in an upwelling environment. Mar Ecol Prog Ser 32:203-215

Širović A, Hildebrand JA, Wiggins SM, McDonald MA, Moore SE, Thiele D (2004) Seasonality of blue and fin whale calls and the influence of sea ice in the western Antarctic Peninsula. Deep Sea Res II 51:2327-2344

Sourisseau M, Simard Y, Saucier FJ (2006) Krill aggregation in the St. Lawrence system, and supply of krill to the whale feeding grounds in the estuary from the gulf. Mar Ecol Prog Ser 314:257-270

Stenson GB, Lien J, Lawson J, Seton R (2003) Ice entrapments of blue whales in southwest Newfoundland: 1968-1992. In: Lesage V, Hammill MO (eds) Proceedings of the workshop on the development of research priorities for the Northwest Atlantic blue whale population, 20-21 Nov 2002. DFO Can Sci Advis Secr Proc Ser 2003/031, p 15-17. www.dfo-mpo.gc.ca/csas

Sulikowski JA, Galuardi B, Bubley W, Furey NB, Driggers WB III, Ingram GW Jr, Tsang PCW (2010) Use of satellite tags to reveal the movements of spiny dogfish Squalus acanthias in the western North Atlantic Ocean. Mar Ecol Prog Ser 418:249-254

Editorial responsibility: Andrew Read, Beaufort, North Carolina, USA
Torres-Florez JP, Olson PA, Debrinana-Romano L, Rosenbaum HC, Ruiz J, LeDuc R, Hucke-Gaete R (2015) First documented migratory destination for eastern South Pacific blue whales. Mar Mamm Sci 31:1580-1586

Turchin P (1991) Translating foraging movements in heterogeneous environments into the spatial distribution of foragers. Ecology 72:1253-1266

Turchin P (1998) Quantitative analysis of movements: measuring and modeling population redistribution in animals and plants. Sinauer Associates, Sunderland, MA

Visser F, Hartman KL, Pierce GJ, Valavanis VD, Huisman J (2011) Timing of migratory baleen whales at the Azores in relation to the North Atlantic spring bloom. Mar Ecol Prog Ser 440:267-279

*Wenzel FW, Mattila DK, Clapham PJ (1988) Balaenoptera musculus in the Gulf of Maine. Mar Mamm Sci 4: 172-175

Whitehead H (2013) Trends in cetacean abundance in the Gully submarine canyon, 1988-2011, highlight a $21 \%$ per year increase in Sowerby's beaked whales (Mesoplodon bidens). Can J Zool 91:141-148

* Wiens JA, Stenseth NC, Van Horne B, Ims RA (1993) Ecological mechanisms and landscape ecology. Oikos 66: 369-380

*Wilson RP, Vandenabeele SP (2012) Technological innovation in archival tags used in seabird research. Mar Ecol Prog Ser 451:245-262

* Wimmer T, Whitehead H (2004) Movements and distribution of northern bottlenose whales, Hyperoodon ampullatus, on the Scotian Slope and in adjacent waters. Can J Zool 82:1782-1794

*Wong SNP, Whitehead H (2014) Seasonal occurrence of sperm whales (Physeter macrocephalus) around Kelvin Seamount in the Sargasso Sea in relation to oceanographic processes. Deep Sea Res I 91:10-16

Worm B, Lotze HK, Myers RA (2003) Predator diversity hotspots in the blue ocean. Proc Natl Acad Sci USA 100: 9884-9888

Submitted: July 26, 2016; Accepted: May 6, 2017

Proofs received from author(s): June 23, 2017 